\title{
Impact of 4-methylbenzylidene camphor, daidzein, and estrogen on intact and osteotomized bone in osteopenic rats
}

\author{
Marina Komrakova*, Stephan Sehmisch*, Mohammad Tezval, Ulrich Schmelz ${ }^{1}$, Holm Frauendorf ${ }^{2}$, \\ Thomas Grueger, Thomas Wessling, Carolin Klein, Miriam Birth, Klaus M Stuermer and \\ Ewa K Stuermer
}

Department of Trauma Surgery and Reconstructive Surgery, University of Goettingen, Robert-Koch Street 40, 37075 Goettingen, Germany

${ }^{1}$ Subdivision of General Hygiene and Environmental Health, Department of Medical Microbiology, University of Goettingen, Humboldallee 34a, 37073 Goettingen, Germany

${ }^{2}$ Department of Organic and Biomolecular Chemistry, University of Goettingen, Tammannstrasse 2, 37077 Goettingen, Germany

(Correspondence should be addressed to M Komrakova; Email: komrakova@yahoo.com)

*(M Komrakova and S Sehmisch contributed equally to this work)

\begin{abstract}
The study investigated the influence of 4-methylbenzylidene camphor (4-MBC), daidzein, and estradiol-17 $\beta$-benzoate $\left(E_{2}\right)$ on either intact or osteotomized cancellous bone in ovariectomized (Ovx) rats. Three-month old Ovx rats were fed with soy-free (SF) diet over 8 weeks; thereafter, bilateral transverse metaphyseal osteotomy of tibia was performed and rats were divided into groups: rats fed with SF diet and SF diet supplemented with 4-MBC (200 mg), daidzein $(50 \mathrm{mg})$, or $\mathrm{E}_{2}(0.4 \mathrm{mg})$ per kilogram body weight. After 5 or 10 weeks, computed tomographical, biomechanical, histological, and ashing analyses were performed in lumbar spine and tibia of 12 rats from each group. 4-MBC and $\mathrm{E}_{2}$ improved bone parameters in lumbar spine and tibia, were not favorable for osteotomy healing, and decreased serum osteocalcin level. However, daidzein improved bone parameters to a lesser extent and facilitated osteotomy healing. For lumbar spine, the bone mineral density was $338 \pm 9,346 \pm 5,361 \pm 6$,
\end{abstract}

and $360 \pm 5 \mathrm{mg} / \mathrm{cm}^{3}$ in SF, daidzein, 4-MBC, and $\mathrm{E}_{2}$, respectively, after 10 weeks. For tibia, the yield load was $98 \pm 5,114 \pm 3,90 \pm 2$, and $52 \pm 4 \mathrm{~N}$ in SF, daidzein, $4-\mathrm{MBC}$, and $\mathrm{E}_{2}$, respectively, after 10 weeks. Serum daidzein was $54 \pm 6 \mathrm{ng} / \mathrm{ml}$ in daidzein group and equol was not detected. $A l p$ and $I g f 1$ genes were down-regulated in callus after daidzein and $\mathrm{E}_{2}$ compared with 4-MBC (week 5). The response of bone tissue and serum markers of bone metabolism could be ordered: daidzein $<4-\mathrm{MBC}<\mathrm{E}_{2}$. Treatments were more effective after 5 vs 10 weeks. In SF group, bone structure was impaired after 5 weeks and improved after 10 weeks probably due to adaptation mechanisms to osteoporosis. In conclusion, it is conceivable that 4-MBC may improve bone tissue in osteoporotic organisms; osteoporotic patients with fractures could benefit from daidzein treatment.

Journal of Endocrinology (2011) 211, 157-168

\section{Introduction}

Osteoporosis is a disease characterized by a decrease in bone mass and deterioration in bone structure with a consequent increase in bone fragility and risk of fracture. The bone loss is most related to estrogen deficiency and age- and lifestylerelated processes (Turner et al. 1994). Cancellous bone is more metabolically active than cortical bone, and its mass and structural integrity are more severely affected by osteoporosis (Eriksen et al. 1990). Therefore, cancellous bone is more prone to fracture than cortical bone. However, most of the previous studies on bone healing were conducted using cortical bone (Hoang-Kim et al. 2009). When fracture occurs, healing is impaired in osteoporotic organisms. Decrease in mineralized tissue, poorly connected microstructure in newly developed callus, and diminished biomechanical properties have been reported for osteoporotic fracture healing in rat (Namkung-Matthai et al. 2001, Yingjie et al. 2007).

Among other anti-osteoporotic drugs, postmenopausal estrogen replacement therapy has been shown to have the most protective effect against osteoporosis in women (Felson et al. 1993). Unfortunately, hormone supplementation has many adverse side effects (Anderson et al. 2004). New strategies for prevention and treatment of osteoporosis and osteoporotic fractures are being developed.

Phytoestrogens are found mainly in soybeans, clover, alfalfa sprouts, and oilseeds such as flaxseed (Glazier \& Bowman 2001). Soy is the major source of phytoestrogens in the human diet. They have estrogenic effect when combining with estrogen receptors (ERs) with preference for ER $\beta$, however, at much lower affinities than estradiol-17 $\beta$-benzoate 
( $\mathrm{E}_{2}$; Anderson \& Garner 1997). In people consuming high amounts of phytoestrogens, lower rates of cardiovascular disease, breast, prostate and colon cancer, menopausal symptoms, and osteoporosis have been documented. However, some authors reported no effects of phytoestrogens on human health (Cornwell et al. 2004). Phytoestrogens have potential promise for the prevention and treatment of osteoporosis; however, their favorable effect on bone cells has not been proven unambiguously yet (Cornwell et al. 2004). They are already commercially available as a dietary supplement, though they may have the potential for effectively functioning as endocrine disruptors (Mueller et al. 2004). Daidzein and genistein are the prevalent phytoestrogens in soy and are under investigation because of their estrogen-like effect (Picherit et al. 2000, Setchell \& Lydeking-Olsen 2003, Komrakova et al. 2009). Genistein has been demonstrated to inhibit bone resorption and stimulate bone mineralization; however, it was not favorable for tibia healing (Setchell \& Lydeking-Olsen 2003, Kolios et al. 2009). Daidzein was reported to prevent bone loss in young (Ishida et al. 1998) and adult (Picherit et al. 2000) ovariectomized (Ovx) rats; its effect on osteoporotic fracture healing is unknown.

Ultraviolet filters frequently used in cosmetics have an estrogenic effect when consumed by animals (Schlumpf et al. 2008). The u.v. filters reach organisms via food chain and skin penetration (Hany \& Nagel 1995, Schlumpf et al. 2008). 4-Methylbenzylidene camphor (4-MBC) exhibits the highest acute estrogenic in vivo activity in the group of u.v. filters studied (Schlumpf et al. 2001). 4-MBC binds competitively to ERs with distinct preference for ER $\beta$ (Schlumpf et al. 2004) and prevents ovariectomy-induced bone loss in rat (Seidlová-Wuttke et al. 2006). Though 4-MBC has been reported to be an endocrine disruptor (Carou et al. 2009), it is approved for use in the European Union for cosmetic products and non-food products. 4-MBC is relevant not only from a toxicological point of view but is also interesting because of its protective effect on osteoporotic bone and muscle (Seidlová-Wuttke et al. 2006, Komrakova et al. 2009).

Some studies reported the effect of daidzein and 4-MBC on intact bone tissue (Picherit et al. 2000, Seidlová-Wuttke et al. 2006). However, the impact of these substances on the healing processes of fractured bone has not been studied so far. Part of this study has been presented in Komrakova et al. (2009) showing a positive effect of estrogen, 4-MBC, and daidzein on muscle tissue. This paper also included preliminary qualitative analysis of tibia healing. Lower rates of complete healing were detected in rats treated with 4-MBC and estrogen compared with daidzein-treated rats or untreated Ovx rats (Komrakova et al. 2009).

This study was undertaken to further understand the influence of daidzein, 4-MBC, and estrogen treatments on either intact or osteotomized cancellous bone in ovariectomy-induced osteopenic rats. Lumbar vertebral region and tibia metaphysis were chosen for this study. Lumbar spine was studied intact, whereas tibia was osteotomized in the metaphysis to investigate the healing processes.

\section{Materials and Methods}

The study was approved by the District Government of Braunschweig and conformed to German animal protection laws.

The study comprised 96 female Sprague-Dawley rats (Harlan Winkelmann, Borchen, Germany) of 12 weeks of age. After 1-week acclimatization period, animals were randomly assigned into four groups, each of 24 rats and, thereafter, bilaterally Ovx using i.p. ketamine $(90 \mathrm{mg} / \mathrm{kg}$ of body weight (BW); Medistar, Holzwickede, Germany) and xylazine $(7.5 \mathrm{mg} / \mathrm{kg}$ of $\mathrm{BW}$; Riemser, Greifswald, Insel Riems, Germany). Rats were housed three to four in standard cages under $12 \mathrm{~h}$ light: $12 \mathrm{~h}$ darkness regimes at a constant temperature of $22 \pm 1{ }^{\circ} \mathrm{C}$. Rats were fed on a soy-free (SF) pelleted diet (Table 1).

After 8 weeks, when osteopenic changes in bone were established (Kalu 1991), both the tibiae of the rat were osteotomized according to the method described earlier (Stuermer et al. 2010). Briefly, after anesthetizing using ketamine and xylazine, rats received $100 \mathrm{mg}$ Decentan s.c. (Merck) and 4 mg Rimadyl s.c. (Pfizer, Karlsruhe, Germany)

Table 1 Composition of soy-free diet. Ssniff special diets $\mathrm{GmbH}$, SM R/M (10 mm; Soest, Germany)

\section{Ingredients}

Crude protein $(\%)$

Crude fat $(\%)$

Crude fiber $(\%)$

Crude ash $(\%)$

Calcium (\%)

Phosphorus (\%)

Sodium (\%)

Magnesium (\%)

Potassium (\%)

Iron $(\mathrm{mg} / \mathrm{kg})$

Manganese $(\mathrm{mg} / \mathrm{kg})$

Zinc $(\mathrm{mg} / \mathrm{kg})$

Copper $(\mathrm{mg} / \mathrm{kg})$

lodine $(\mathrm{mg} / \mathrm{kg})$

Selenium $(\mathrm{mg} / \mathrm{kg})$

Cobalt (mg/kg)

Vitamin A (IU/kg)

Vitamin $\mathrm{D}_{3}(\mathrm{IU} / \mathrm{kg})$

Vitamin $\mathrm{E}(\mathrm{mg} / \mathrm{kg})$

Vitamin $\mathrm{K}(\mathrm{mg} / \mathrm{kg})$

Vitamin $B_{1}$ (thiamine; $\mathrm{mg} / \mathrm{kg}$ )

Vitamin $B_{2}$ (riboflavin; $\mathrm{mg} / \mathrm{kg}$ )

Vitamin $B_{6}$ (pyridoxine; $\mathrm{mg} / \mathrm{kg}$ )

Vitamin $B_{12}$ (cobalamin; $\mu \mathrm{g} / \mathrm{kg}$ )

Biotin $(\mu \mathrm{g} / \mathrm{kg})$

Pantothenic acid (mg/kg)

Folic acid $(\mathrm{mg} / \mathrm{kg})$

Nicotinic acid $(\mathrm{mg} / \mathrm{kg})$

Choline chloride $(\mathrm{mg} / \mathrm{kg})$

${ }^{a}$ The diet contains mainly potato protein, can contain corn, sugar beet pulp products. 
per kilogram of BW. Thereafter, tibiae were sawn transversely in the metaphysis followed by fixation with the aid of a T-shaped titan plate with four screws. Rimadyl was given twice a day for 2 days following osteotomy.

After operation, animals were fed with special diets. Group 1 (SF) received SF diet (Table 1) serving as a control. Group 2 (4-MBC) was subjected to SF diet supplemented with 4-MBC $(5 \mathrm{~g} / \mathrm{kg}$ of diet). Group 3 (daidzein) received SF diet supplemented with daidzein $(1 \mathrm{~g} / \mathrm{kg}$ diet $)$. Group $4\left(\mathrm{E}_{2}\right)$ received $\mathrm{SF}$ diet containing $\mathrm{E}_{2}(10 \mathrm{mg} / \mathrm{kg}$ diet $)$. The diets were produced by Ssniff special diets $\mathrm{GmbH}$ (Soest, Germany). Daidzein (98\% pure) was provided by Changzhou Dahua Imp. and Exp. (Group) Corp. Ltd (Jiangsu, China). 4-MBC (Eusolex 6300) was obtained from Merck. The daily food intake was calculated on a weekly weighing of food. All animals had free access to food and water throughout the experiment. A daily dosage of 4-MBC averaged $200 \mathrm{mg} / \mathrm{kg}$ BW. Daily dosages of daidzein and estrogen were an average of 50 and $0.4 \mathrm{mg} / \mathrm{kg} \mathrm{BW}$ respectively. The doses of $4-\mathrm{MBC}$ and daidzein were chosen based on the previous studies showing a favorable effect on osteoporotic bones (Picherit et al. 2000, Seidlová-Wuttke et al. 2006). The daily intake of $0.4 \mathrm{mg}$ estrogen per kilogram BW results in serum estrogen concentration of about $40 \mathrm{pg} / \mathrm{ml}$ (Vortherms 2006). This is within the physiological range reported for healthy female rats (Krinke 2000).

The labeling of new bone formation during tibia healing was done in vivo (Rahn 1976). The fluorescence dyes xylenol orange (XO, $90 \mathrm{mg} / \mathrm{kg} \mathrm{BW})$, calcein green (CG, $10 \mathrm{mg} / \mathrm{kg}$ $\mathrm{BW})$, alizarin complexone (AC, $30 \mathrm{mg} / \mathrm{kg} \mathrm{BW}$ ), and tetracycline (TC, $25 \mathrm{mg} / \mathrm{kg} \mathrm{BW}$ ) were injected s.c. In rats treated up to 5 weeks, the dyes were applied on day $13(\mathrm{XO})$, on day 18 (CG), on days 22 and 24 (AC), and on day 35 (TC) after osteotomy respectively. Rats treated up to 10 weeks received $\mathrm{XO}$ on day 36, CG on day 47, AC on days 56 and 59 , and TC on day 70 after osteotomy.

After 5 or 10 weeks of treatments, 12 animals from each treatment group were anesthetized (ketamine and xylazine) and the first lumbar vertebral body (L1) and both tibiae were analyzed by means of computed tomography (CT). Thereafter, rats were decapitated and blood samples were collected for analyses. Immediately, the lumbar vertebral bodies and tibiae were dissected free of soft tissues. Lumbar region of vertebra was stored at $-20^{\circ} \mathrm{C}$ until further analyses. The second lumbar vertebral body (L2) was used for histomorphometrical analyses. The third lumbar vertebral body (L3) was ashed. The fourth vertebral body (L4) was tested biomechanically. One tibia, chosen randomly, was used for histological analyses. Newly formed callus at the osteotomy line of contralateral tibia was sampled for gene expression analyses after 5 weeks, the time when the callus is still forming and the resorption has not begun, and stored at $-80^{\circ} \mathrm{C}$. Callus clips contained osteotomized cortical bone ends, which were bridged with callus (Fig. 1).
Flat-panel volume CT

Before being decapitated, rats anesthetized using ketamine and xylazine were placed in a flat-panel volume CT (fpVCT; GE Global Research, Niskayuna, NY, USA), a non-clinical CT prototype (Missbach-Guentner et al. 2007). The lumbar region of rat vertebra and tibiae were scanned using a two flat-panel detectors consisting of $1024 \times 1024$ detector elements with an element size of $200 \times 200 \mu \mathrm{m}$. Data were acquired by using 360 rows of each detector, $80 \mathrm{kVp}, 100 \mathrm{~mA}$, and 1000 projection images per rotation within $8 \mathrm{~s}$. Data were reconstructed with a voxel size of about $100 \mu \mathrm{m}$ and analyzed on an Advantage Workstation (version 4.2, General Electric Health Care, Milwaukee, WI, USA). They were initially assessed in Hounsfield units and then converted into bone mineral density (BMD $\left.\left(\mathrm{mg} / \mathrm{cm}^{3}\right)\right)$ using three hydroxyapatite standards of several mineral densities. BMD of L1 was calculated (Sehmisch et al. 2009a). Tibia data could not be interpreted properly because of the artifacts caused by the presence of the titan plate with screws and, therefore, were not taken into account.

\section{Biomechanical analyses}

Mechanical testing device of Zwick/Roell (type 145660 Z020/TND, Ulm, Germany) was used in the analyses. The fourth lumbar vertebral body was evaluated by a compression test with the load applied at the caudal end plate along the cranio-caudal axis using specially developed stamp and support (Sehmisch et al. 2009b). Tibia was evaluated by a three-point bending test. It was loaded $2 \mathrm{~mm}$ distal from osteotomy line of ventromedial aspect. The tip of the stamp was a mobile roller with a circular notch in the center (Stuermer et al. 2006). After fixing the bone with a preload of $1 \mathrm{~N}$, the measurements were performed at a feed motion rate of $5 \mathrm{~mm} / \mathrm{min}$ and recorded with the aid of Test Expert Software (Zwick/Roell). L4 was loaded until the first plastic deformation occurred. Non-destructive measurements of tibia were stopped when elastic deformation reached yield point. Stiffness, a slope of the linear rise of the curve; yield load, end point of elastic deformation; and additionally maximal compressive strength (Fmax) for L4, the highest strength of bone resistance, were determined.

\section{Histological analyses}

The entire L2 and tibia were subjected to the sequential ascending concentration of ethanol and embedded in methylmethacrylate (Merck). Thereafter, sections of $150 \mu \mathrm{m}$ thickness were cut using diamond saw microtome (Leica SP 1600, Leica Instruments GmbH, Nussloch, Germany). Vertebral body was cut sagittally. Tibia was cut at the right angle to the ventromedial aspect longitudinally. Central representative sections were microradiographed with the aid of faxitron Cabinet X-ray system (Hewlett-Packard, Buffalo Grove, IL, USA) using Kodak 100 NIF Industrex Film (SR 45, Kodak). Four L2 sections and three tibia sections were 
Week 5
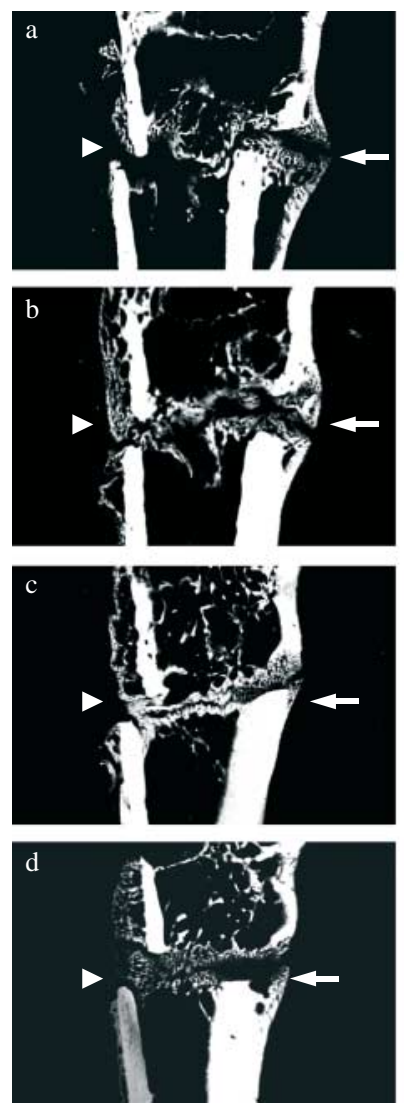
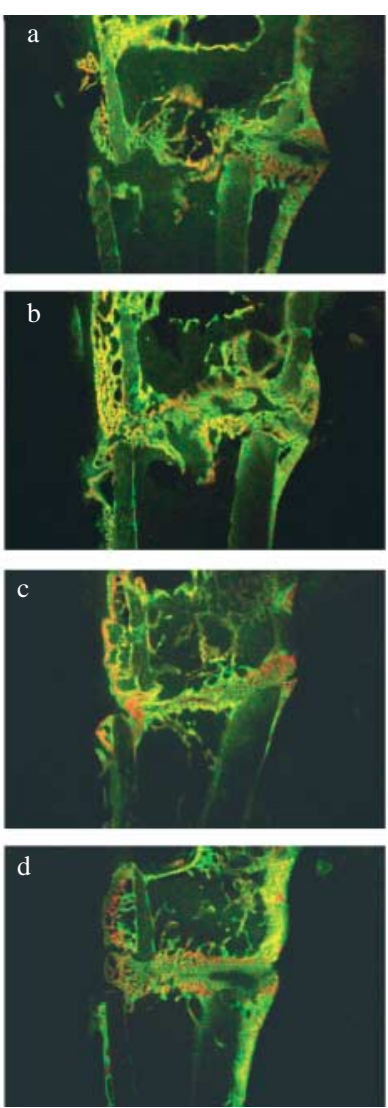
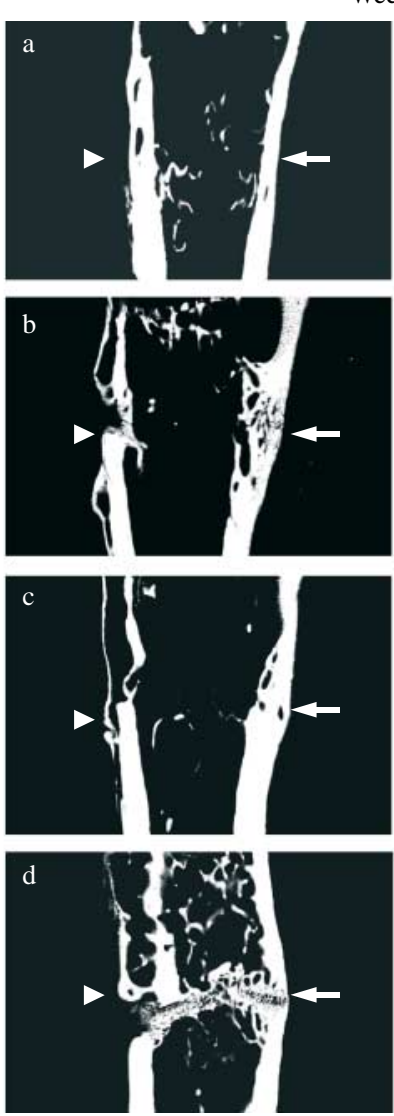

Week 10
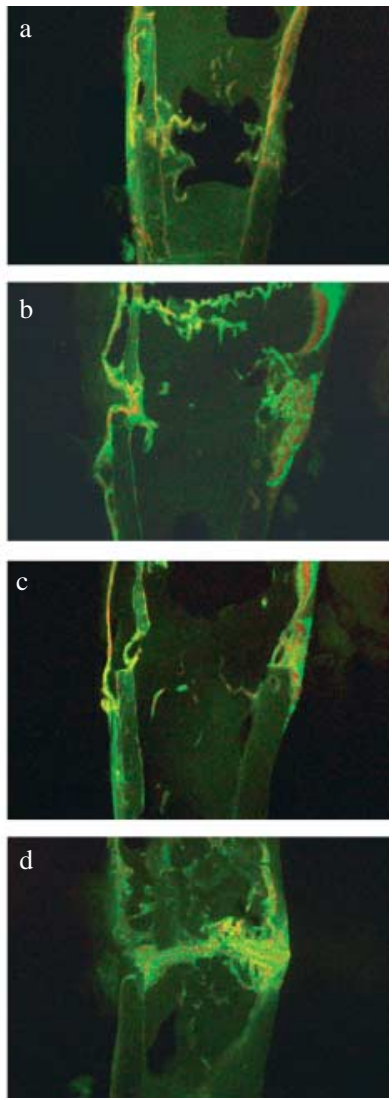

Figure 1 Microradiographs (columns 1 and 3) and fluorochrome-labeled sections (columns 2 and 4) of the metaphysis of tibia cut longitudinally either after 5 or 10 weeks of osteotomy healing in ovariectomized rats subjected to (a) soy free diet; (b) daidzein; (c) 4-MBC; and (d) estradiol-17ß-benzoate. Arrowheads, ventromedial aspect; arrows, dorsal aspect.

microradiographed and digitalized using a digital camera (Leica DC300F) and a zoom stereo microscope (Leica MZ75) with the aid of QWin image analysis program (Leica, Bensheim, Germany). Vertebral body analysis included the following measurements: cortical volume ratio of total bone volume, trabecular bone area, average trabecular width, number of trabecular nodes, and number of nodes per square millimeter.

The measurement area of tibia extended $1.5 \mathrm{~mm}$ proximally and $1.5 \mathrm{~mm}$ distally from the osteotomy site. Three regions were identified: 1) plate side; ventromedial; 2) dorsal; and 3) endosteal (Fig. 1). Cortical width and density distal to osteotomy, periosteal callus width and density, endosteal callus density, number of trabecular nodes, and trabecular width were determined using microradiographs (Fig. 1, first column). Osseous callus area labeled with fluorochromes was determined by analysis of section images according to the regions of interest after 5 weeks of healing. After 10 weeks, the areas of old bone existing pre-osteotomy and of new bone formed after osteotomy were measured using microradiographs. The areas were distinguished by the absence or the presence of fluorochrome labeling when analyzing section images (Fig. 1, second column).

\section{Ashing}

L3 was dried in a muffle oven at $110^{\circ} \mathrm{C}$ for $24 \mathrm{~h}$ and, thereafter, was ashed at $750^{\circ} \mathrm{C}$ for $1 \mathrm{~h}$. Ash weight was expressed as a ratio of cylindrical vertebral volume, which was calculated based on the height and the diameter of vertebral body. Fifty milligrams of bone ash were dissolved in $10 \%$ nitric acid and diluted with distilled water. Calcium content was determined by atomic absorption spectrometric method (atomic absorption spectrometer 4100, hollow cathode lamp N066-1285, PerkinElmer, Rodgau, Germany) according to CEN (2002). Orthophosphate content was assayed by a colorimetric procedure (spectral photometer DM4, Zeiss, Oberkochen, Germany) according to CEN (2004).

\section{Gene expression analyses}

Samples of the callus were homogenized followed by total RNA extraction with the aid of RNeasy Mini Kit (Qiagen). Quantity of RNA was assessed by a photometer (Biometra, Goettingen, Germany). RNA samples (100 ng) were then reverse transcribed using Superscript RNase H-reverse 
transcriptase (Promega) and stored at $-20{ }^{\circ} \mathrm{C}$. Expression of rat genes, alkaline phosphatase (Alp), insulin-like growth factor 1 (Igf1), osteocalcin (Oc), and tartrate-resistant acid phosphatase (Trap) were determined by quantitative real-time PCR (qRT-PCR) based on SYBR Green detection using iCycler (CFX96, Bio-Rad Laboratories). Ready-to-use primer pairs were obtained from Qiagen (QuantiTect Primer Assays). QRT-PCR was performed according to the manufacturer's instructions (Qiagen). Relative gene expression was calculated using $2^{-\Delta \Delta C_{\mathrm{T}}}$ method (Livak \& Schmittgen 2001) for each gene of interest, where $\Delta \Delta C_{\mathrm{T}}=$ $\left(C_{\mathrm{T}}\right.$ treatment group gene $-C_{\mathrm{T}}$, reference gene $\beta-2$ microglobulin $(\mathrm{Mg}))-\left(C_{\mathrm{T}}\right.$ intact group gene $-C_{\mathrm{T}}$, reference gene $\beta-2 \mathrm{Mg})$. In intact group $(n=10)$, female rats were intact non-Ovx, non-osteotomized, untreated, maintained under the same conditions as the treatment groups, were of the same age, and had a comparable BW. Samples were collected from the metaphyseal part of tibia. Gene expression in the intact group was taken as one.

\section{Serum analyses}

Daidzein and equol were measured in serum of SF and daidzein-treated rats using HPLC method coupled with a u.v. detector and electrospray ionization mass spectrometry (ESI-MS). Samples $(1 \mathrm{ml})$ were hydrolyzed with the aid of glucuronidase (Helix Promatia $\beta$-glucuronidase type H1, Sigma) and, thereafter, extraction was done using polymeric solid-phase method according to the manufacturer's protocol (Strata X SPE, Phenomenex, Torrance, CA, USA). After elution of samples in absolute alcohol, they were dried in a vacuum centrifuge (Univapo $150 \mathrm{H}$, Uniequip, Planegg, Germany) over $5 \mathrm{~h}$. The dried sample residues were dissolved in $100 \mu \mathrm{l}$ water/acetonitrile $(70 / 30 \mathrm{v} / \mathrm{v})$ and submitted to HPLC-u.v./MS analysis. HPLC was performed using a Rheos 4000 pump (Flux Instruments, Basel, Switzerland) together with an autoinjector AS-1555 (Jasco, GrobUmstadt, Germany) and a degasser 3492 (Kontron Instruments, Neufahrn, Germany). For separation, an HPLC column YMC-Pack ODS-A C18 $(100 \times 2.1 \mathrm{~mm}, 3 \mu \mathrm{m}$ particle size) was used with water containing $0.05 \%$ formic acid (eluent A) and acetonitrile containing $0.05 \%$ formic acid (eluent $\mathrm{B}$ ) and an eluent flow of $0 \cdot 3 \mathrm{ml} / \mathrm{min}$; HPLC program: $70 / 30 \mathrm{~A} / \mathrm{B}$ to $10 / 90 \mathrm{~A} / \mathrm{B}$ within $15 \mathrm{~min}, 10 / 90 \mathrm{~A} / \mathrm{B}$ for 7 min. Each sample was injected twofold (injection volume, $5 \mu \mathrm{l})$. Mass spectrometric detection was carried out on an ion trap mass spectrometer LCQ (Finnigan, San Jose, CA, USA) equipped with an electrospray ion source (spray voltage $4.5 \mathrm{kV}$, sheath gas $80 \mathrm{AU}$, auxiliary gas $20 \mathrm{AU}$, capillary temperature $240^{\circ} \mathrm{C}$ ) recording in the negative ion mode (ESI) a mass range of $230-280 \mathrm{~m} / \mathrm{z}$ (for quantitation: [M-H] $\mathrm{m} / \mathrm{z} 253 \cdot 4)$. Accompanying measurements were done using a u.v./vis diode array detector (Finnigan Surveyor PDA, Thermo Electron, San Jose, CA, USA) with a selected wavelength of $280 \mathrm{~nm}(278-282 \mathrm{~nm})$. For quantitation, an external calibration was established using rat plasma samples spiked with the following concentrations: $0 \cdot 05,0 \cdot 10,0 \cdot 25$, $0.50 \mu \mathrm{g} / \mathrm{ml}$, and enriched according to the solid phase extraction (SPE) procedure described above.

Analyses of Oc and Alp were conducted at the Department of Clinical Chemistry, University of Goettingen. Serum Oc was determined by electrochemiluminescence immunoassay analysis and Alp by colorimetric assay using automated chemistry analyzer (Roche/Hitachi Modular) and commercially available kits (Roche) according to the manufacturer's instructions (Roche Diagnostic GmbH).

\section{Statistical analyses}

ANOVA $(P<0 \cdot 05)$ were applied to reveal the impact of two fixed effects (diets, duration of their administration) and their interactions on the bone and callus parameters (SAS version 9.1; SAS Institute, Cary, NC, USA). Differences between individual means were estimated using Scheffé test $(P<0 \cdot 05)$. Data are shown as means and S.E.M. The Kruskal-Wallis and Dunn multiple comparison tests were used for analyses of relative gene expression (GraphPad Prism 4.0; GraphPad Software, San Diego, CA, USA). At least nine repetitions per treatment group were done.

\section{Results}

\section{Serum analyses}

Serum concentration of daidzein averaged $54 \mathrm{ng} / \mathrm{ml}$ (from 28 to $75 \mathrm{ng} / \mathrm{ml}$, s.E.M. $=6 \mathrm{ng} / \mathrm{ml}$ ) in daidzein group, whereas equol was not detected in these animals (limit of detection $\sim 0 \cdot 1 \mu \mathrm{g} / \mathrm{ml}$ (u.v. detection, wavelength $280 \mathrm{~nm}$ ). In serum of SF animals, neither daidzein (limit of detection $\sim 5 \mathrm{ng} / \mathrm{ml}$, ESI-MS $[\mathrm{M}-\mathrm{H}]-\mathrm{m} / \mathrm{z}$ 253.4) nor equol was detected.

Serum Oc was at the lowest level in the $\mathrm{E}_{2}$ group (Fig. 2). In the 4-MBC group, it was lower than that in the SF group, but not different from that in the daidzein group. Daidzein treatment did not change Oc level $(P>0 \cdot 05)$. Serum Alp concentration did not differ significantly between the treatment groups (Fig. 2).
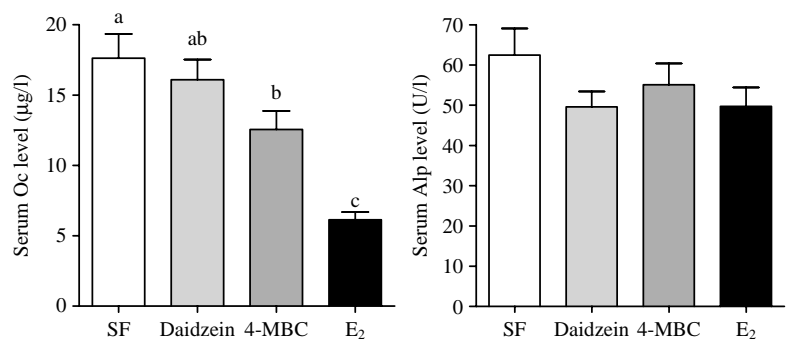

Figure 2 Serum osteocalcin (Oc) and alkaline phosphatase (Alp) levels in ovariectomized rats subjected to soy-free diet (SF), daidzein, 4-MBC, or estradiol-17 $\beta$-benzoate $\left(E_{2}\right)$ abc, means with different superscripts differ significantly between treatment groups $(P<0 \cdot 05$, Scheffé test $)$. 
Table 2 Flat-panel volume computed tomography (FpVCT), ashing, and histological analyses of lumbar vertebral bodies in ovariectomized rats fed with soy-free (SF), daidzein, 4-methylbenzylidene camphor (4-MBC), or estradiol-17 $\beta$-benzoate ( $E_{2}$ ) supplemented diet up to 5 or 10 weeks

\begin{tabular}{|c|c|c|c|c|c|c|c|c|c|}
\hline & \multirow[b]{2}{*}{ Weeks } & \multicolumn{2}{|l|}{ SF } & \multicolumn{2}{|c|}{ Daidzein } & \multicolumn{2}{|l|}{ 4-MBC } & \multicolumn{2}{|l|}{$E_{2}$} \\
\hline & & Mean & S.E.M. & Mean & S.E.M. & Mean & S.E.M. & Mean & S.E.M. \\
\hline \multicolumn{10}{|l|}{ Parameters } \\
\hline \multicolumn{10}{|l|}{ FpVCT (L1) } \\
\hline \multirow[t]{2}{*}{$\mathrm{BMD}\left(\mathrm{mg} / \mathrm{cm}^{3}\right)$} & 5 & 335 & 8 & 340 & 4 & $343^{x}$ & 5 & 350 & 5 \\
\hline & 10 & $338^{\mathrm{a}}$ & 9 & $346^{\mathrm{ab}}$ & 5 & $361^{\mathrm{Yb}}$ & 6 & $360^{b}$ & 5 \\
\hline \multicolumn{10}{|l|}{ Ashing (L3) } \\
\hline \multirow[t]{2}{*}{$\mathrm{Ca}^{2+} / \mathrm{PO}_{4}^{3-}$} & 5 & $1 \cdot 23^{\mathrm{Xa}}$ & $0 \cdot 01$ & $1 \cdot 25^{\times a b}$ & $0 \cdot 004$ & $1 \cdot 26^{\mathrm{Xb}}$ & $0 \cdot 01$ & $1 \cdot 26^{\mathrm{Xb}}$ & $0 \cdot 01$ \\
\hline & 10 & $1 \cdot 27^{\mathrm{Ya}}$ & $0 \cdot 004$ & $1 \cdot 27^{\mathrm{Yab}}$ & $0 \cdot 01$ & $1 \cdot 29^{\mathrm{Yb}}$ & $0 \cdot 004$ & $1 \cdot 29^{\mathrm{Yb}}$ & $0 \cdot 01$ \\
\hline \multicolumn{10}{|l|}{ Histology (L2) } \\
\hline \multirow[t]{2}{*}{ Cortical volume $(\%)$} & 5 & $49^{\mathrm{Xa}}$ & 2 & $54^{\mathrm{Xab}}$ & 2 & $56^{\mathrm{Xb}}$ & 2 & $56^{\mathrm{xb}}$ & 2 \\
\hline & 10 & $67^{Y}$ & 2 & $63^{Y}$ & 2 & $66^{y}$ & 1 & $65^{y}$ & 1 \\
\hline Trabecular area $\left(\mathrm{mm}^{2}\right)$ & 5 & $1 \cdot 4^{\mathrm{Xa}}$ & $0 \cdot 1$ & $1 \cdot 6^{x b}$ & $0 \cdot 1$ & $1 \cdot 7^{\mathrm{Xb}}$ & $0 \cdot 1$ & $1 \cdot 7^{\mathrm{Xb}}$ & $0 \cdot 1$ \\
\hline \multirow[t]{2}{*}{ Number of nodes $/ \mathrm{mm}^{2}$} & 5 & $22^{\mathrm{Xa}}$ & 1 & $25^{\mathrm{ab}}$ & 1 & $26^{\mathrm{Xb}}$ & 1 & $27^{\mathrm{Xb}}$ & 1 \\
\hline & 10 & $26^{\mathrm{Ya}}$ & 1 & $27^{\mathrm{a}}$ & 1 & $31^{\mathrm{Yb}}$ & 1 & $34^{\mathrm{Yb}}$ & 1 \\
\hline
\end{tabular}

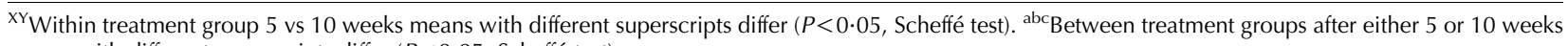
means with different superscripts differ $(P<0 \cdot 05$, Scheffé test).

\section{Vertebral body}

fpVCT analysis (L1) BMD increased significantly in the 4-MBC group during experiment (5 vs 10 weeks, Table 2). Between the treatment groups, the differences were observed after 10 -week treatment. BMD was higher $(P<0.05)$ in the 4-MBC and $\mathrm{E}_{2}$ groups than in the SF group. In the daidzein group, BMD did not differ significantly from other groups (Table 2).

Biomechanical analyses (L4) Biomechanical properties of vertebral body improved in the daidzein and SF groups during experiment (5 vs 10 weeks; Fig. 3). Between the groups, the differences were observed in stiffness during the whole treatment period, whereas in yield load and F-max, they were found only after 5 weeks of treatments. Stiffness was higher in the $\mathrm{E}_{2}$ and 4-MBC groups compared with that in the daidzein and SF groups on week 5 (Fig. 3). After 10 weeks, stiffness in the daidzein group increased to the level observed in the $\mathrm{E}_{2}$ and 4-MBC groups, whereas in the SF group, it remained at the lowest level. Yield load and Fmax were significantly higher in rats fed with a supplemented diet compared with those measured in the SF group on week 5, whereas after 10 weeks, no significant differences were found (Fmax week 5: SF, $138 \pm 11 \mathrm{~N}$; 4-MBC, $179 \pm 10 \mathrm{~N}$; daidzein, $170 \pm 9 \mathrm{~N} ; \mathrm{E}_{2}, 183 \pm 7 \mathrm{~N}$ and week $10: \mathrm{SF}, 188 \pm 9 \mathrm{~N} ; 4-\mathrm{MBC}$, $189 \pm 7 \mathrm{~N}$; daidzein, $\left.184 \pm 9 \mathrm{~N} ; \mathrm{E}_{2}, 203 \pm 8 \mathrm{~N}\right)$.

Ashing (L3) Ash to volume ratio did not change in the SF, daidzein, and 4-MBC groups, whereas in $\mathrm{E}_{2}$ group, the ratio increased significantly during the treatment period (5 vs 10 weeks, Table 2). Between the groups, there were no differences in inorganic weight. The molar ratio of calcium to orthophosphate increased significantly in all the groups during the experiment (Table 2). The differences between the groups were revealed after 5 and 10 weeks of treatments. In the 4-MBC and $\mathrm{E}_{2}$ groups, $\mathrm{Ca}^{2+} / \mathrm{PO}_{4}^{3-}$ ratio was significantly enhanced compared with that observed in the SF group. In the daidzein group, it increased to the level of 4-MBC- and $\mathrm{E}_{2}$-treated rats, but was not different from that detected in the SF group $(P>0 \cdot 05)$.
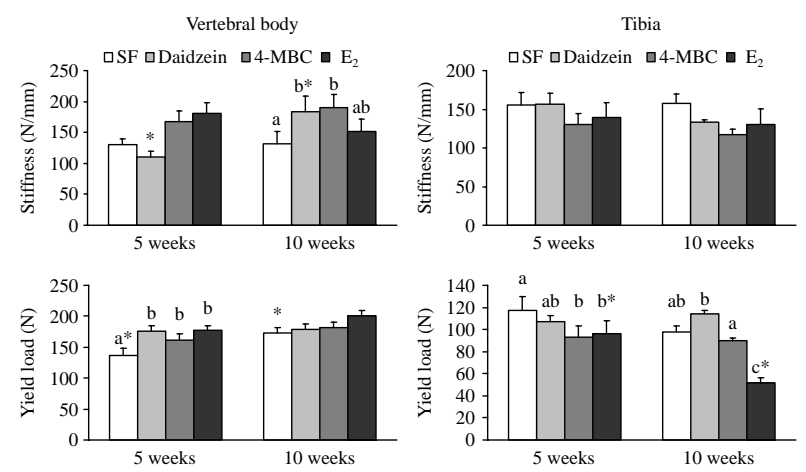

Figure 3 Biomechanical analyses of lumbar vertebral body (L4) and tibia performed after 5 or 10 weeks in ovariectomized rats subjected to soy-free diet (SF), daidzein, 4-MBC, or estradiol-17 $\beta$-benzoate $\left(\mathrm{E}_{2}\right)$ abc, means with different superscripts differ between treatment groups at either week 5 or 10 ; ${ }^{*}$ means with different superscripts differ within treatment group, 5 vs 10 weeks $(P<0 \cdot 05$, Scheffé test). 
Histological analyses (L2) Cortical volume increased significantly in all groups during the period of supplemented feeding ( 5 vs 10 weeks, Table 2 ). The differences between the groups were revealed after 5 weeks of treatments. In the 4-MBC and $\mathrm{E}_{2}$ groups, the cortical volume was higher than that in the SF group. In the daidzein group, it did not differ significantly from that in other groups. After 10 weeks of treatments, the differences were not found. Trabecular parameters were enhanced in all the groups ( 5 vs 10 weeks). Trabecular area was larger in the daidzein, 4-MBC, and $\mathrm{E}_{2}$ groups than in the SF group after 5 weeks, whereas after 10 weeks, it did not differ between the groups. Trabecular width did not differ between the groups. Number of trabecular nodes and trabecular density were higher in the 4-MBC and $\mathrm{E}_{2}$ groups compared with those in the $\mathrm{SF}$ and daidzein groups during the experiment (Table 2).

\section{Tibia}

Biomechanical analyses Neither treatment nor duration of the treatments affected $(P<0 \cdot 05)$ the stiffness of the callus (Fig. 3). Yield load decreased in the $\mathrm{E}_{2}$ group during the experiment (5 vs 10 weeks). Between the groups, yield load differed, being lower in the 4-MBC and $\mathrm{E}_{2}$ groups than in the
SF group after 5 and 10 weeks. In the daidzein group, it was at the level observed in the SF group.

Histological analyses Five weeks after osteotomy, the bone healing underwent reparative stage when callus bridged and stabilized osteotomized bone (Fig. 1, week 5). In the SF and daidzein groups, extended callus was formed; however, it was less compact than that in the 4-MBC and $\mathrm{E}_{2}$ groups (Fig. 1a-d). Ten weeks post-osteotomy corresponded to the remodeling stage. Osteotomy gap was united in most of the animals of SF, daidzein, and 4-MBC groups (Fig. 1a-c, week 10). Callus has been remodeled with newly formed compact bone and its shape was close to the original shape of the bone. In the $\mathrm{E}_{2}$ group, callus was remodeled at a lower rate and still large area of callus has been seen (Fig. 1d, week 10).

Quantitative analyses of microradiographic images of sections showed that cortical and callus width decreased during the experiment (5 vs 10 weeks, Table 3 ). Cortical density improved in the SF group after 10 weeks of healing. Callus density increased in all the groups after week 10 . Trabecular properties were not affected by the duration of treatments $(P>0 \cdot 05)$. Between the groups, the differences were revealed in cortical and trabecular width, callus density,

Table 3 Microradiographic analysis of tibia sections at the osteotomy site at ventromedial and dorsal aspects and endosteally in ovariectomized rats fed from the first day after osteotomy with soy-free (SF), daidzein, 4-methylbenzylidene camphor (4-MBC), or estradiol$17 \beta$-benzoate $\left(E_{2}\right)$ supplemented diet up to 5 or 10 weeks performed using microradiographic images

\begin{tabular}{|c|c|c|c|c|c|c|c|c|c|}
\hline & & SF & & Daidze & & 4-MBC & & $\mathbf{E}_{2}$ & \\
\hline & Weeks & Mean & S.E.M. & Mean & S.E.M. & Mean & S.E.M. & Mean & S.E.M. \\
\hline Parameters & & & & & & & & & \\
\hline Ventromedial & & & & & & & & & \\
\hline Cortical with $(\mathrm{mm})$ & 5 & $0 \cdot 38^{\mathrm{Xa}}$ & $0 \cdot 02$ & $0 \cdot 36^{\mathrm{Xa}}$ & $0 \cdot 02$ & $0 \cdot 47^{\mathrm{Xb}}$ & $0 \cdot 03$ & $0 \cdot 51^{\mathrm{Xb}}$ & $0 \cdot 02$ \\
\hline & 10 & $0 \cdot 18^{\mathrm{Yab}}$ & $0 \cdot 02$ & $0 \cdot 15^{\mathrm{Ya}}$ & $0 \cdot 01$ & $0 \cdot 22^{\mathrm{Yb}}$ & $0 \cdot 02$ & $0 \cdot 21^{\mathrm{Yab}}$ & $0 \cdot 03$ \\
\hline Cortical density (\%) & 5 & $95^{x}$ & 2 & 98 & 1 & 98 & $0 \cdot 3$ & 96 & 1 \\
\hline & 10 & $99^{\mathrm{Y}}$ & $0 \cdot 2$ & 98 & 1 & 99 & $0 \cdot 3$ & 99 & $0 \cdot 4$ \\
\hline Callus width (mm) & 5 & $0 \cdot 49^{\mathrm{x}}$ & $0 \cdot 04$ & $0 \cdot 49^{x}$ & $0 \cdot 03$ & $0 \cdot 50^{x}$ & $0 \cdot 04$ & $0 \cdot 43^{x}$ & $0 \cdot 3$ \\
\hline & 10 & $0 \cdot 27^{\mathrm{Y}}$ & $0 \cdot 02$ & $0 \cdot 23^{\mathrm{Y}}$ & $0 \cdot 02$ & $0 \cdot 29^{Y}$ & $0 \cdot 3$ & $0 \cdot 26^{Y}$ & $0 \cdot 03$ \\
\hline Callus density (\%) & 5 & $62^{\mathrm{a}}$ & 2 & $59^{\mathrm{Xa}}$ & 3 & $48^{\mathrm{Xb}}$ & 3 & $41^{\mathrm{Xb}}$ & 4 \\
\hline & 10 & $66^{a}$ & 3 & $80^{\mathrm{Yb}}$ & 2 & $80^{\mathrm{Yb}}$ & 3 & $80^{\mathrm{Yb}}$ & 2 \\
\hline Dorsal & & & & & & & & & \\
\hline Cortical width (mm) & 5 & $0 \cdot 44^{\mathrm{Xa}}$ & $0 \cdot 04$ & $0 \cdot 51^{\mathrm{Xa}}$ & $0 \cdot 03$ & $0 \cdot 59^{\mathrm{Xb}}$ & $0 \cdot 03$ & $0 \cdot 62^{\mathrm{Xb}}$ & $0 \cdot 04$ \\
\hline & 10 & $0 \cdot 24^{\mathrm{Ya}}$ & $0 \cdot 03$ & $0 \cdot 14^{\mathrm{Yb}}$ & $0 \cdot 01$ & $0 \cdot 19^{\mathrm{Yab}}$ & $0 \cdot 02$ & $0 \cdot 20^{\mathrm{Yab}}$ & $0 \cdot 01$ \\
\hline Cortical density (\%) & 5 & 98 & $0 \cdot 4$ & 99 & $0 \cdot 3$ & 99 & $0 \cdot 2$ & 98 & $0 \cdot 4$ \\
\hline & 10 & 99 & $0 \cdot 4$ & 95 & 1 & 98 & $0 \cdot 4$ & 99 & $0 \cdot 3$ \\
\hline Callus width (mm) & 5 & $1 \cdot 01^{x}$ & $0 \cdot 1$ & $0.93^{x}$ & $0 \cdot 1$ & $0 \cdot 80^{x}$ & $0 \cdot 1$ & $0 \cdot 72^{x}$ & $0 \cdot 1$ \\
\hline & 10 & $0.35^{\mathrm{Y}}$ & $0 \cdot 03$ & $0 \cdot 48^{\mathrm{Y}}$ & $0 \cdot 03$ & $0.52^{\mathrm{Y}}$ & $0 \cdot 1$ & $0.55^{\mathrm{Y}}$ & $0 \cdot 04$ \\
\hline Callus density (\%) & 5 & $54^{\mathrm{Xa}}$ & 2 & $64^{b}$ & 3 & $54^{\mathrm{Xa}}$ & 3 & $47^{\mathrm{Xa}}$ & 3 \\
\hline & 10 & $74^{\mathrm{Ya}}$ & 3 & $65^{b}$ & 3 & $63^{\mathrm{Yb}}$ & 4 & $75^{\mathrm{Ya}}$ & 2 \\
\hline Endosteal & & & & & & & & & \\
\hline Callus density (\%) & 5 & $34^{\mathrm{a}}$ & 3 & $45^{\mathrm{b}}$ & 3 & $37^{\mathrm{Xab}}$ & 3 & $39^{\mathrm{Xab}}$ & 3 \\
\hline & 10 & $43^{\mathrm{a}}$ & 4 & $47^{\mathrm{a}}$ & 5 & $47^{\mathrm{Ya}}$ & 5 & $76^{\mathrm{Yb}}$ & 2 \\
\hline Number of trabecular nodes $(n)$ & 5 & $5^{\mathrm{ab}}$ & 1 & $4^{\mathrm{a}}$ & 1 & $7^{\mathrm{ab}}$ & 2 & $9^{b}$ & 2 \\
\hline & 10 & $2^{a}$ & $0 \cdot 4$ & $3^{\mathrm{a}}$ & 1 & $3^{a}$ & 1 & $8^{\mathrm{b}}$ & 3 \\
\hline Trabecular width $(\mu \mathrm{m})$ & 5 & 3 & $0 \cdot 2$ & 4 & 1 & 4 & $0 \cdot 2$ & 4 & 1 \\
\hline & 10 & $4^{\mathrm{a}}$ & 1 & $4^{\mathrm{a}}$ & $0 \cdot 2$ & $5^{\mathrm{ab}}$ & 1 & $6^{\mathrm{b}}$ & 1 \\
\hline
\end{tabular}

${ }^{\mathrm{XY}}$ Means with different superscripts differ within treatment group 5 vs 10 weeks $\left(P<0 \cdot 05\right.$, Scheffé test). ${ }^{\text {abc }}$ Means with different superscripts differ $(P<0 \cdot 05$, Scheffé test) between treatment groups after either 5 or 10 weeks. 
Table 4 Fluorescence analysis of osseous callus at the osteotomy site at ventromedial and dorsal aspects and endosteally after 5 weeks and of bone after 10 weeks in ovariectomized rats fed from the first day after osteotomy either with soy-free (SF), daidzein, 4-methylbenzylidene camphor $(4-\mathrm{MBC})$, or estradiol-17 $\beta$-benzoate $\left(\mathrm{E}_{2}\right)$ supplemented diet

\begin{tabular}{|c|c|c|c|c|c|c|c|}
\hline \multicolumn{2}{|l|}{ SF } & \multicolumn{2}{|c|}{ Daidzein } & \multicolumn{2}{|l|}{ 4-MBC } & \multicolumn{2}{|l|}{$E_{2}$} \\
\hline Mean & S.E.M. & Mean & S.E.M. & Mean & S.E.M. & Mean & S.E.M. \\
\hline $1485^{a}$ & 168 & $1135^{\mathrm{b}}$ & 148 & $806^{c}$ & 63 & $562^{c}$ & 58 \\
\hline 1861 & 220 & 1736 & 175 & 1676 & 177 & 1223 & 158 \\
\hline 1335 & 110 & 1221 & 94 & 1247 & 93 & 1074 & 105 \\
\hline $5851^{\mathrm{a}}$ & 349 & $5371^{a b}$ & 251 & $4727^{\mathrm{bc}}$ & 241 & $4050^{\mathrm{C}}$ & 269 \\
\hline $2605^{a}$ & 132 & $3119^{b}$ & 143 & $3083^{b}$ & 222 & $3448^{b}$ & 201 \\
\hline $873^{a}$ & 52 & $799^{\mathrm{a}}$ & 35 & $1066^{b}$ & 83 & $1276^{b}$ & 111 \\
\hline $3472^{a}$ & 153 & $3917^{a b}$ & 161 & $4149^{b c}$ & 260 & $4724^{c}$ & 259 \\
\hline
\end{tabular}

${ }^{\mathrm{abc}}$ Means with different superscripts differ between treatment groups after either 5 or 10 weeks $(P<0 \cdot 05$, Scheffé test).

and number of trabecular nodes. Cortical width was higher in the $\mathrm{E}_{2}$ and 4-MBC groups compared with the SF and daidzein groups. Ventral callus density was lower in the 4-MBC and $\mathrm{E}_{2}$ groups than in the other two groups after 5 weeks and increased after 10 weeks, whereas in the SF group, it remained at the lowest level (Table 3). Dorsal and endosteal callus had the highest density in the daidzein group after 5 weeks. After 10 weeks, it remained at this level in the daidzein group, whereas in other groups, it was enhanced, reaching the highest level in the $\mathrm{SF}$ and $\mathrm{E}_{2}$ groups at the dorsal aspect and in the $E_{2}$ group endosteally. Cortical density and callus width were not affected by the treatments $(P>0 \cdot 05)$. The number of trabecular nodes was higher in the $\mathrm{E}_{2}$ group compared with those in other groups after 10 weeks. Trabecular width increased in the $\mathrm{E}_{2}$ group versus those in the SF and daidzein groups (Table 3).

After 5 weeks of healing, analysis of fluorochrome-labeled sections revealed significantly larger callus area in the SF group compared with that in the $4-\mathrm{MBC}$ and $\mathrm{E}_{2}$ groups (Table 4). In the daidzein group, it did not differ significantly from the SF and 4-MBC groups. After 10 weeks of healing, the result was quite opposite. The smallest area of newly formed bone was found in the SF group (Table 4). Old bone area was larger in the $4-\mathrm{MBC}$ and $\mathrm{E}_{2}$ groups than that in the $\mathrm{SF}$ and daidzein groups. Correspondingly, total bone area was larger in the 4-MBC and $\mathrm{E}_{2}$ groups compared to that in the SF group. In the daidzein group, total bone area did not differ from the SF and 4-MBC groups.

Gene expression $A l p$ and $I g f 1$ gene were down-regulated in the daidzein and $\mathrm{E}_{2}$ groups, reaching significant level in the daidzein versus 4-MBC for $\mathrm{Alp}$ and in $\mathrm{E}_{2}$ versus 4-MBC for Igf1 after week 5 (Fig. 4). In the 4-MBC group, the gene expression was on the level detected in the SF group. Oc and Trap gene expressions did not differ significantly among the groups.

\section{Discussion}

In this study, we investigated the effect of dietary u.v. filter 4-MBC or phytohormone daidzein on either intact or osteotomized cancellous bone and compared that with untreated osteopenic control and with the standard estrogen replacement method. The animal model was ovariectomyinduced osteopenic rat. Ovx rats develop severe osteopenia within a few weeks and can be served as a model of postmenopausal osteoporosis (Kalu 1991). Ovariectomy was confirmed by the atrophied uterine horns in the SF, daidzein,
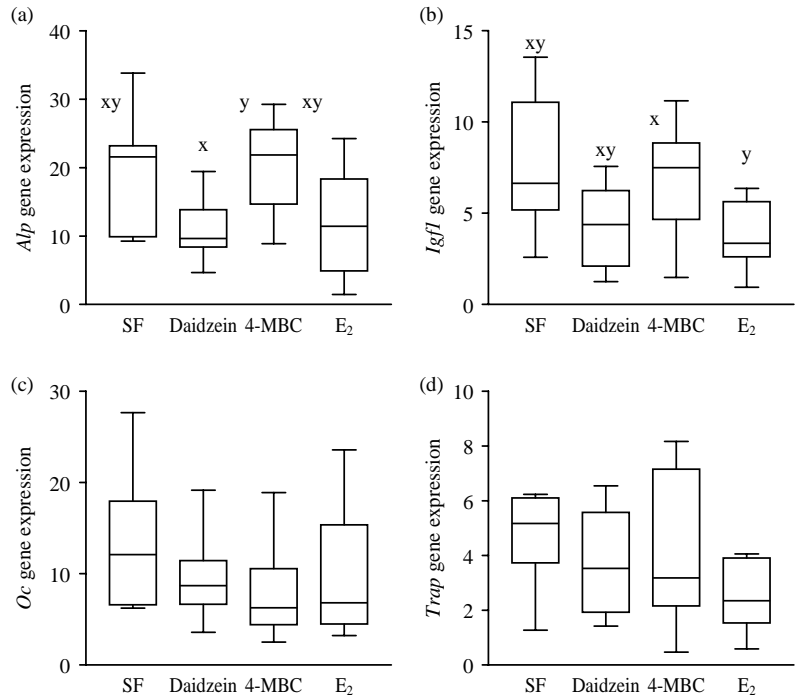

Figure 4 Box plot illustrating relative mRNA expression level of (a) Alp, (b) Igf1, (c) Oc, and (d) Trap genes in tibia callus of ovariectomized rats subjected to either soy-free diet (SF), daidzein, 4-MBC, or estradiol-17 $\beta$-benzoate $\left(E_{2}\right)$ at week 5 after osteotomy. (xy) medians with different letters differ significantly $(P<0 \cdot 05$, Dunn test). 
and 4-MBC groups. Estrogen supplementation increased uterine weight significantly, whereas daidzein and 4-MBC supplementation showed no effect (Komrakova et al. 2009).

Treatment with 4-MBC or $\mathrm{E}_{2}$ resulted in an enhanced BMD of vertebral body after 10 weeks, whereas calcium to orthophosphate ratio was increased after both 5 and 10 weeks. Daidzein slightly enhanced bone parameters to the level of 4-MBC and $\mathrm{E}_{2}$ groups, but was not different from those in the SF group. These results partly explained the improved biomechanical properties in vertebral body of treated rats. Elastic properties of the bone (stiffness) were higher in treated groups during the whole treatment period; yield load and Fmax were enhanced after 5 weeks of treatments. These results are derived mainly from the bone structure (cortical volume and trabecular area), which was improved in these rats after 5 weeks too. Apparently, daidzein, 4-MBC, and $\mathrm{E}_{2}$ improving elastic properties affected not only osseous structures but also non-calcified collagen matrix. The mechanical properties of the bone have been shown to depend also on changes in the collagen structures (Burstein et al. 1975). Thus, estrogen, 4-MBC, and daidzein treatments improved lumbar vertebral properties, but to different extents. The effect of 4-MBC was stronger and more comparable with estrogen, whereas daidzein showed mild effect on bone.

The enhancement of BMD, biomechanical properties, calcium content, and the improvement of cortical and cancellous bone parameters observed in the course of treatments (5 vs 10 weeks) not only in treated groups but also in untreated SF group may be explained by the adaptation mechanisms to the potentially negative effect of osteoporosis. Ovariectomy in 3-month-old rat causes an initial rapid phase of cancellous bone loss during the first 100 days that is coincident with maximal increase in bone turnover, later bone turnover stabilized and slowly declined after 270 days (Wronski et al. 1989, Kalu 1991). Ten weeks of supplemented feeding in this study corresponded to 126 days after Ovx. Furthermore, Ovx rats may exhibit some protection against bone loss for an extended period, e.g. increased BW in SF rats (Komrakova et al. 2009). From the other side, it is possible that daidzein and 4-MBC reacting similar to estrogen may facilitate the rats to restore their physical activity, which was reduced after osteotomy, more rapidly (Komrakova et al. 2009). A decrease in physical activity in Ovx rats has been reported, whereas estrogen replacement normalized its level (Kadi et al. 2002). The more rapid return to the normal physical activity after osteotomy may additionally affect some bone parameters (yield load, Fmax, cortical volume, and trabecular area) and be responsible for the enhanced response to the treatments observed 5 weeks post-osteotomy.

Similar to the effects observed in the vertebrae, 4-MBC showed stronger effect compared with daidzein on cortical and trabecular bone in the tibia metaphysis. 4-MBC similar to $\mathrm{E}_{2}$ increased cortical width after 5 weeks and improved trabecular parameters during the experiment. Daidzein showed less effect. It is known that reduced cortical width in Ovx rats is a result of accelerated bone metabolism with remodeling-modeling imbalance (Wronski et al. 1985), whereas estrogen (Turner et al. 1994) and probably 4-MBC improved cortical width depressing bone turnover. Substantial reduction in cortical width observed 10 weeks after osteotomy may be explained by the biomechanical effect of a stable T-plate osteosynthesis. During rat movement, axial loading passed the T-plate, thus possessing less force on the cortical bone that could probably result in the reduction of its width.

Analyzing fracture healing and callus properties, it was revealed that after 5 weeks of treatments daidzein showed the most favorable effect improving callus density, and 4-MBC and $\mathrm{E}_{2}$ maintained the callus density at the level of SF rats. After 10 weeks of treatment, estrogen supplementation resulted in a denser callus; however, biomechanical properties were diminished after $\mathrm{E}_{2}$ and 4-MBC supplementation. Biomechanical parameters in the daidzein group were not impaired. The results published previously can explain the differences observed in biomechanical properties (Komrakova et al. 2009). Percentage of animals representing osseous callus bridging of osteotomy gap was in SF, $55 \%$; daidzein, $75 \%$; 4-MBC, $58 \%$; and $\mathrm{E}_{2}, 46 \%$ after 5 weeks and the osteotomy was healed in SF, 92\%; daidzein, 92\%; 4-MBC, 67\%; and $\mathrm{E}_{2}$, $60 \%$ of rats after 10 weeks (Komrakova et al. 2009). Low bridging rate in the 4-MBC group suggested impaired fracture healing. Estrogen has been demonstrated to have diverse effects on bone healing in Ovx rats. Whereas Stuermer et al. (2010) reported improved callus and bone parameters after estrogen supplementation, Jahng \& Kim (2000) and Komrakova et al. (2010) found no advantage of estrogen treatment for fracture healing. In this study, despite anti-catabolic stimulus, estrogen treatment in Ovx rats impeded healing processes.

Comparing the callus areas between the treatment groups, it was revealed that ovariectomy resulted in a formation of a larger callus after 5 weeks in the SF group, whereas after 10 weeks, less old and new bone was measured in these rats compared with that in the other groups $\left(\mathrm{E}_{2}, 4-\mathrm{MBC}\right.$, and daidzein). The callus and bone tissue were resorbed at a higher rate in the SF group. Previous studies showed accelerated bone metabolism in Ovx rats, whereas estrogen supplementation maintains lower equilibrated metabolism presented in the bone of intact rats (Wronski et al. 1988, Komrakova et al. 2010). Decreased level of serum Oc in estrogen-treated rats confirms the latter.

Though the effects of estrogen and 4-MBC on bone tissue and serum markers of bone turnover were similar, the expression of bone genes differed in the callus. As reported previously, mRNA expression level of bone genes does not correspond to the serum level of bone markers (Komrakova et al. 2010). In this study, the expression of genes $A l p$, which is essential for matrix mineralization, and Igf1, which enhances bone formation, was on the level of untreated control after 4-MBC treatment, whereas daidzein and $\mathrm{E}_{2}$ down-regulated these genes. It was shown that under 4-MBC 
treatment, serum levels of Oc and cross/RatLaps were increased which indicated enhanced activities of osteoblasts and osteoclasts (Seidlová-Wuttke et al. 2006). In contrast, we observed decreased serum level of Oc in 4-MBC-treated rats. Estrogen is known to affect osteoclasts suppressing production of receptor activator of nuclear factor kappa B ligand, which is required for osteoclast development. Estrogen also suppresses production of bone-resorbing cytokines, tumor necrosis factor $\alpha$, prostaglandins, and increases production of transforming growth factor $\beta$, which induces osteoclast apoptosis (Clarke \& Khosla 2010). Daidzein suppress osteoclast activity and stimulates osteogenesis in vitro (Setchel \& Ledyking-Olsen 2003). The favorable effect of daidzein on bone is often attribute to equol, its active metabolite that has a 100-fold higher affinity for ERs compared with daidzein (Sathyamoorthy \& Wang 1997). Brown \& Setchell (2001) measured equol in all rats fed with a different soy diet. In this study, rats had measurable amount of daidzein in serum, whereas the presence of equol was not confirmed.

ERs, not typed to that time, have been found in fracture callus, suggesting that estrogen plays a role in the regeneration of bone after fracture (Monaghan et al. 1992). The physiological effects of estrogens are mediated predominantly by $\mathrm{ER} \alpha$ whose activation reduces bone resorption, increasing trabecular volume. ER $\beta$ may play a dual role: as a competitor of $\mathrm{ER} \alpha$ at normal or low $\mathrm{E}_{2}$ levels and as an alternative for $\mathrm{ER} \alpha$, inhibiting bone turnover and preventing bone loss in the presence of high $\mathrm{E}_{2}$ levels (Sims et al. 2002). The preferential affinity of daidzein and 4-MBC to ER $\beta$ (Anderson \& Garner 1997, Schlumpf et al. 2004) and altered hormonal status in Ovx rats may influence the responses of skeleton. Furthermore, BW and body fat composition are mainly influenced by ER $\alpha$-specific signaling (Ohlsson et al. 2000). Estrogen deficiency led to an increased BW. The increased weight enhanced mechanical load on the tibia and may promote callus formation and fracture healing in the SF and daidzein rats (Komrakova et al. 2009).

The magnitude of the effect and the exact mechanisms of action of 4-MBC and daidzein on bone tissue are presently elusive or speculative. Both osteoblast and osteoclast are target cells for their action. They combine with ERs and act via this mechanism, apparently with different activity. Furthermore, they may also have effects on other cellular mechanisms independent of the ERs such as enzyme inhibition and interference with cell cycle progression reported for phytoestrogens (Anderson \& Garner 1997).

Though the action of 4-MBC and daidzein remained unclear, the response of the bone tissue and serum markers of bone metabolism to the treatments can be ordered as follows: daidzein $<4-\mathrm{MBC}<\mathrm{E}_{2}$. Similar systemic effect was observed on BW and food consumption of the experimental animals (Komrakova et al. 2009). Probably, estrogen and 4-MBC were favorable for amelioration of osteoporotic bone tissue inhibiting bone resorption to a greater extent than daidzein. However, this was not favorable for callus formation and remodeling. Daidzein effect was lesser on osteoporotic bone that perhaps stimulated osteotomy healing.

Based on the present data, it appeared that treatments had a beneficial effect on bone tissue during the whole treatment period, but were more effective during a short period (5 weeks). Treatments with 4-MBC and estrogen improved cancellous and cortical bone parameters but were not favorable for osteotomy healing. Daidzein had a mild affect, improving bone parameters to a lesser extent, but did facilitate osteotomy healing. Estrogen had the most protective effect on osteoporotic bone tissue; however, it is not a favorable treatment because of the negative side effects observed in humans. It is conceivable that 4-MBC may improve bone tissue in osteoporotic organisms. However, further studies are needed to elucidate the mechanism of 4-MBC action and possible toxic effect on other tissues. Osteoporotic patients with fractures may benefit from daidzein treatment.

\section{Declaration of interest}

The authors declare that there is no conflict of interest that could be perceived as prejudicing the impartiality of the research reported.

\section{Funding}

This study was supported by the German Research Foundation (DFG STU 478/2-1).

\section{Acknowledgements}

The authors thank F Kauer, R Castro-Machguth, and A Witt for their help.

\section{References}

Anderson JJB \& Garner SC 1997 The effect of phytoestrogens on bone. Nutrition Research 17 1617-1632. (doi:10.1016/S0271-5317(97)00156-5) Anderson GL, Limacher M, Assaf AR, Bassford T, Beresford SA, Black H, Bonds D, Brunner R, Brzyski R, Caan B et al. 2004 Effect of conjugated equine estrogen in postmenopausal women with hysterectomy: the women's health initiative randomized controlled trial. Journal of the American Medical Association 291 1701-1712. (doi:10.1001/jama.291.14.1701)

Brown NM \& Setchell KDR 2001 Animal model impacted by phytoestrogens in commercial chow: implications for pathways influences by hormones. Laboratory Investigation 81 735-747. (doi:10.1038/labinvest.3780282)

Burstein AH, Zika JM, Heiple KG \& Klein L 1975 Contribution of collagen and mineral to the elastic-plastic properties of bone. Journal of Bone and Joint Surgery 57 956-961.

Carou ME, Deguiz ML, Reynoso R, Szwarcfarb B, Carbone S, Moguilevsky JA, Scacchi P \& Ponzo OJ 2009 Impact of the u.v.-B filter 4-(methylbenzylidene)-camphor (4-MBC) during prenatal development in the neuroendocrine regulation of gonadal axis in male and female adult rats. Environmental Toxicology and Pharmacology 27 410-414. (doi:10.1016/j.etap. 2009.01.007)

CEN 2002 European committee for standardization. Determination of Calcium and Magnesium. Atomic absorption spectrometric method. EN ISO 7980. 1-9. 
CEN 2004 European committee for standardization. Determination of Orthophosphate. Ammonium molybdate spectrometric method. EN ISO 6878. 1-29

Clarke BL \& Khosla S 2010 Physiology of bone loss. Radiologic Clinics of North America 48 483-495. (doi:10.1016/j.rcl.2010.02.014)

Cornwell T, Cohick W \& Raskin I 2004 Dietary phytoestrogens and health. Phytochemistry 65 995-1016. (doi:10.1016/j.phytochem.2004. 03.005)

Eriksen EF, Hodgson SF, Eastell R, Cedel SL, O'Fallon WM \& Riggs BL 1990 Cancellous bone remodeling in type I (postmenopausal) osteoporosis: quantitative assessment of rates of formation, resorption, and bone loss at tissue and cellular levels. Journal of Bone and Mineral Research 5 311-319. (doi:10.1002/jbmr.5650050402)

Felson DT, Zhang Y, Hannan MT, Kiel DP, Wilson PWF \& Anderson JJ 1993 The effect of postmenopausal estrogen therapy on bone density in elderly women. New England Journal of Medicine 329 1141-1146. (doi:10.1056/ NEJM199310143291601)

Glazier MG \& Bowman MA 2001 A review of the evidence for use of phytoestrogens as a replacement for traditional estrogen replacement therapy. Archives of Internal Medicine 161 1161-1172. (doi:10.1001/archinte. 161.9.1161)

Hany J \& Nagel R 1995 Nachweis von u.v.-filtersubstanzen in muttermilch. Deutsche Lebensmittel-Rundschau 91 341-345.

Hoang-Kim A, Gelsomini L, Luciani D, Moroni A \& Giannini S 2009 Fracture healing and drug therapies in osteoporosis. Clinical Cases in Mineral and Bone Metabolism 6 136-143.

Ishida H, Uesugi T, Hirai K, Toda T, Nukaya H, Yokotsuka K \& Tsuji K 1998 Preventive effects of the plant isoflavones, daidzein and genistin, on bone loss in ovariectomized rats fed a calcium-deficient diet. Biological and Pharmaceutical Bulletin 21 62-66.

Jahng JS \& Kim HW 2000 Effect of intermittent administration of parathyroid hormone on fractures healing in ovariectomized rats. Orthopedics $\mathbf{2 3}$ 1089-1094.

Kadi F, Karlsson C, Larsson B, Eriksson J, Larval M, Billig H \& Jonsdottir IH 2002 The effects of physical activity and estrogen treatment on rat fast and slow skeletal muscles following ovariectomy. Journal of Muscle Research and Cell Motility 23 335-339. (doi:10.1023/A:1022071114344)

Kalu DN 1991 The ovariectomized rat model of postmenopausal bone loss. Bone and Mineral 15 175-192. (doi:10.1016/0169-6009(91)90124-I)

Kolios L, Sehmisch S, Daub F, Rack T, Tezval M, Stuermer KM \& Stuermer EK 2009 Equol but not genistein improves early metaphyseal fracture healing in osteoporotic rats. Planta Medica 75 459-465. (doi:10.1055/ s-0029-1185380)

Komrakova M, Werner C, Wicke M, Nguyen BT, Sehmisch S, Tezval M, Stuermer KM \& Stuermer EK 2009 Effect of daidzein, 4-methylbenzylidene camphor or estrogen on gastrocnemius muscle of osteoporotic rats undergoing tibia healing period. Journal of Endocrinology 201 253-622. (doi:10.1677/JOE-08-0521)

Komrakova M, Stuermer EK, Werner C, Wicke M, Kolios L, Sehmisch S, Tezval M, Daub F, Martens T, Witzenhausen P et al. 2010 Effect of human parathyroid hormone hPTH (1-34) applied at different regimes on fracture healing and muscle in ovariectomized and healthy rats. Bone 47 480-492. (doi:10.1016/j.bone.2010.05.013)

Krinke GJ 2000. The Laboratory Rat, The Handbook of Experimental Animals. pp 756. Eds G Bullock \& T Bunton. San Diego: Academic Press.

Livak KJ \& Schmittgen TD 2001 Analysis of relative gene expression data using real-time quantitative PCR and the $2^{-\Delta \Delta C_{\mathrm{T}}}$ method. Methods 25 402-408. (doi:10.1006/meth.2001.1262)

Monaghan BA, Kaplan FS, Lyttle CR, Fallon MD, Boden SD \& Haddad JG 1992 Estrogen receptors in fracture healing. Clinical Orthopaedics and Related Research $280277-280$

Missbach-Guentner J, Dullin C, Zientkowska M, Domeyer-Missbach M, Kimmina S, Obenauer S, Kauer F, Stühmer W, Grabbe E, Vogel WF et al. 2007 Flat-panel detector-based volume computed tomography: a novel 3D imaging technique to monitor osteolytic bone lesions in a mouse tumor metastasis model. Neoplasia 9 755-765. (doi:10.1593/neo.07466)
Mueller SO, Simon S, Chae K, Metzler M \& Korach KS 2004 Phytoestrogens and their human metabolites show distinct agonistic and antagonistic properties on estrogen receptor $\alpha(\mathrm{ER} \alpha)$ and $\mathrm{ER} \beta$ in human cells. Toxicological Science 80 14-25. (doi:10.1093/toxsci/kfh147)

Namkung-Matthai H, Appleyard R, Jansen J, Hao Lin J, Maastricht S, Swain M, Mason RS, Murrell GA, Diwan AD \& Diamond T 2001 Osteoporosis influences the early period of fracture healing in a rat osteoporotic model. Bone 28 80-86. (doi:10.1016/S8756-3282(00)00414-2)

Ohlsson C, Hellberg N, Parini P, Vidal O, Bohlooly M, Rudling M, Lindberg MK, Warner M, Angelin B \& Gustafsson JA 2000 Obesity and disturbed lipoprotein profile in estrogen receptor-alpha-deficient male mice. Biochemical and Biophysical Research Communications 278 640-645. (doi:10.1006/bbrc.2000.3827)

Picherit C, Coxam V, Bennetau-Pelissero C, Kati-Coulibaly S, Davicco M-J, Lebecque P \& Barlet J-P 2000 Daidzein is more efficient than genistein in preventing ovariectomy-induced bone loss in rats. Journal of Nutrition 130 1675-1681.

Rahn DA 1976 The fluorochrome sequence labelling of the bone. Nova Acta Leopoldina 44 249-255.

Sathyamoorthy N \& Wang TT 1997 Differential effects of dietary phyto-oestrogens daidzein and equol on human breast cancer MCF-7 cells. European Journal of Cancer 33 2384-2389. (doi:10.1016/S09598049(97)00303-1)

Schlumpf M, Cotton B, Conscience M, Haller V, Steinmann B \& Lichtensteiger W 2001 In vitro and in vivo estrogenicity of u.v. screeens. Environmental Health Perspectives 109 239-244. (doi:10.1289/ehp. 01109239)

Schlumpf M, Jarry H, Wuttke W, Ma R \& Lichtensteiger W 2004 Estrogenic activity and estrogen receptor beta binding of the u.v. filter 3-benzylidene camphor. Comparison with 4-methylbenzylidene camphor. Toxicology 199 109-120. (doi:10.1016/j.tox.2004.02.015)

Schlumpf M, Durrer S, Faass O, Ehnes C, Fuetsch M, Gaille C, Henseler M, Hofkamp L, Maerkel K, Reolon S et al. 2008 Developmental toxicity of u.v. filters and environmental exposure: a review. International Journal of Andrology 31 144-151. (doi:10.1111/j.1365-2605.2007.00856.x)

Sehmisch S, Dullin C, Zaroban A, Tezval M, Rack T, Schmelz U, Seidlova-Wuttke D, Dunkelberg H, Wuttke W, Marten K et al. 2009a The use of flat panel volumetric computed tomography (fpVCT) in osteoporosis research. Academic Radiology 16 394-400. (doi:10.1016/j.acra.2008.09.017)

Sehmisch S, Erren M, Rack T, Tezval M, Richter J, Seidlova-Wuttke D, Wuttke W, Stuermer KM \& Stuermer EK 2009 b A new biomechanical test for intact rat lumbar vertebral bodies to study antiosteoporotic drugs. Short term effects of parathyroid hormone on rat lumbar vertebrae. Spine $\mathbf{3 4}$ 2014-2021. (doi:10.1097/BRS.0b013e3181afe846)

Seidlová-Wuttke D, Jarry H, Christoffel J, Rimoldi G \& Wuttke W 2006 Comparison of effects of estradiol $\left(\mathrm{E}_{2}\right)$ with those of octylmethoxycinnamate (OMC) and 4-methylbenzylidene camphor (4-MBC) - 2 filters of u.v. light - on several uterine, vaginal and bone parameters. Toxicology and Applied Pharmacology 210 246-254. (doi:10.1016/j.taap.2005.05.006)

Setchell KDR \& Lydeking-Olsen E 2003 Dietary phytoestrogens and their effect on bone: evidence from in vitro and in vivo, human observational, and dietary intervention studies. American Journal of Clinical Nutrition $\mathbf{7 8}$ 593S-609S

Sims NA, Dupont S, Krust A, Clement-Lacroix P, Minet D, Resche-Rigon M, Gaillard-Kelly M \& Baron R 2002 Detection of estrogen receptors reveals a regulatory role for estrogen receptor- $\beta$ in bone remodeling in female but not in males. Bone 30 18-25. (doi:10.1016/S8756-3282(01)00643-3)

Stuermer EK, Seidlová-Wuttke D, Sehmisch S, Rack T, Wille J, Frosch KH, Wuttke W \& Stuermer KM 2006 Standardized bending and breaking test for the normal and osteoporotic metaphyseal tibias of the rat: effect of estradiol, testosterone, and raloxifene. Journal of Bone and Mineral Research 21 89-96. (doi:10.1359/JBMR.050913)

Stuermer EK, Sehmisch S, Rack T, Wenda E, Seidlova-Wuttke D, Tezval M, Wuttke W, Frosch KH \& Stuermer KM 2010 Estrogen and raloxifene improve metaphyseal fracture healing in the early phase of osteoporosis. A new fracture-healing model at the tibia in rat. Langenbeck's Archives of Surgery 395 163-172. (doi:10.1007/s00423-008-0436-x) 
Turner RT, Riggs BL \& Spelsberg TC 1994 Skeletal effects of estrogen. Endocrine Reviews 15 275-300. (doi:10.1210/edrv-15-3-275)

Vortherms T 2006 Effects of daidzein, its metabolite equol, puerarin, quercetin and estradiol on the pituitary and the urogenital tract of the ovariectomized rats. Dissertation Hannover, pp 126 (http://deposit. d-nb.de/cgi-bin/dokserv?idn=98363615x\&dok_var=d1\&dok_ext=pdf\& filename $=98363615 \mathrm{x} . \mathrm{pdf})(07.03 .2011)$.

Wronski TJ, Lowry PL, Walsh CC \& Ignaszewski LA 1985 Skeletal alterations in ovariectomized rats. Calcified Tissue International 37 324-328. (doi:10. 1007/BF02554882)

Wronski TJ, Cintron M, Doherty AL \& Dann LM 1988 Estrogen treatment prevents osteopenia and depresses bone turnover in ovariectomized rats. Endocrinology 123 681-686. (doi:10.1210/endo123-2-681)
Wronski TJ, Dann LM, Scott KS \& Cintron M 1989 Long-term effects of ovariectomy and aging on the rat skeleton. Calcified Tissue International $\mathbf{4 5}$ 360-366. (doi:10.1007/BF02556007)

Yingjie H, Ge Z, Yisheng W, Ling Q, Hung WY, Kwoksui L \& Fuxing P 2007 Changes of microstructure and mineralized tissue in the middle and late phase of osteoporotic fracture healing in rats. Bone 41 631-638. (doi:10. 1016/j.bone.2007.06.006)

Received in final form 23 June 2011

Accepted 29 July 2011

Made available online as an Accepted Preprint 29 July 2011 